\title{
TESTS IN READING IN SYCAMORE SCHOOLS
}

\author{
KARL DOUGLAS WALDO \\ Principal, East Aurora High School, Aurora, Illinois
}

\section{INTRODUCTION}

A short time before I became superintendent of the Sycamore Public Schools (in 1909) the Ward Rational System of Reading had been adopted in the first and second grades. Most of the teachers were enthusiastic over the innovation and declared this system to be superior to the old plan of having each teacher work out her own plan of instruction. Soon, however, one teacher became dissatisfied with the character of the subject-matter in the Ward readers, her objection being the lack of interest shown by the children for the reading material offered. She heard W. W. Howe give an exposition of the phonic method developed by him and used at Whitehall, New York; this discussion was before the regular bimonthly teachers' meeting. 'Soon afterward she asked to be allowed to try that system of reading. This she was permitted to do.

As supervisor, I naturally watched the reading as it was developed through the phonic method and compared it with the work done under the Ward plan and also with the reading of the higher grades which had started their reading with no regular system. With notebook in hand I endeavored to keep a record of the individual work of the three systems for the purpose of comparison. These records were not very satisfactory and were based upon oral reading only, with no attempt to determine the comprehension by the children of the passages read other than that which could be shown by the oral expression.

When I saw how inadequate the comparison, made in this way, proved to be, I looked for some better method of making a record of the work. The attempts of Ayers, Courtis, Thorndike, and others to formulate standard tests suggested the formation of a 
plan for more scientific testing of the reading work. I also wished to test the silent rather than the oral reading, for the former is of much greater importance, not only later in school, but in future life.

I have not endeavored in this investigation to formulate a series of standard tests. If this study should prove to be of any help toward that end, however, I shall feel amply compensated for the effort expended. These statistics may be of some help in the study of children's reading habits and may aid in determining future plans for the teaching of reading.

Working from day to day upon the same problems and in the routine of the school it is often difficult to see that the young people have made any distinct increase in efficiency. The results of this test in showing the large progress made in reading during a period less than six months are of great value. Every teacher was delighted with the improvement made and felt rewarded for her efforts. Even the children were pleased at their own increased efficiency and set to work with a will, vowing to do even better in the future.

An example showing how these tests created an interest in the reading work may more clearly show their value as a means of motivation. Miss Finnegan's third grade, one of the places in which the check tests were given, was found to have the poorest average reading ability of all the third grades in the September test (see Table III). It was not planned originally to give her room any test in the spring. She set to work to bring her grade up to standard and asked that her room might be given a test later with the others. A special test with somewhat similar material was arranged for her. She emphasized the reading work and at least once a week asked the children to reproduce in writing an account of what their reading lesson had contained for that day. No set day was used for this exercise, so that the young people never knew when they might be expected to remember and understand all the reading lesson. This written exercise was done in the language period and correlated these two branches of the curriculum. The children were incited to do their best so that the superintendent never again would find them to be the poorest readers. With these third-graders this plan was a success, for the children fell in with the 
spirit of competition and soon greatly improved their work. By spring they had made the greatest percentage of increase in reproduction and were up to standard in every way when the tests were given. Miss Finnegan's room is not quite typical of the rest of the rooms, yet it shows how a skilful teacher can use such tests to improve the work in her room.

The majority of the teachers welcomed such tests, which gave them an opportunity to measure the results of their own work and to compare these results with the work of other teachers and children. An example of the teacher's attitude is shown by the teacher just mentioned, Miss Finnegan, who offered to count, record, and average the words read and reproduced by the children of her room in order that her grade might in the spring be compared with the other third grades.

The weakness of any phonic system of reading usually is found in the tendency to neglect the thought element because of the desire to perfect the mechanics. Such a test measures both elements of the reading much better than could be done by listening to the oral reading of the children, as is usually done in supervision.

These statements show that as a means of supervision and administration tests like this one are of much utility. Some teachers may doubt the value of the superintendent's criticism or may feel that his opinion of the work in their rooms is unwarranted. After such a test there is no need for the superintendent to criticize. The facts found in this test were shown in the bimonthly teachers' meeting and, after discussion, were accepted by the teachers as indicative of the true situation in the reading work. Knowing the situation is the first step in the direction of effective work, and after that is taken both teachers and superintendent can, in cordial co-operation, set about improving the reading work.

\section{DESCRIPTION OF METHOD}

The method used in these tests was simple and closely resembled the regular work of the school. Each test took about an hour of school time. No attempt was made to emphasize this work, yet the children seemed delighted with the test and many asked for their record afterward. 
The first issue for the year I9I3-I4 of Current Events, a school weekly paper, was used for the tests. This paper is taken regularly by all the children above the fourth grade. However, this issue was not distributed, so that the children never read it except during the two tests. Owing to a mistake the papers were distributed in the eighth grades and were in the possession of the pupils a few hours previous to the test. Not even the teachers knew of the coming test, and as the time was well occupied by the school work only a few of the children in the eighth grade had read any in these papers. Several in each eighth-grade room, when asked whether they had read the paper, replied that they had "looked it over."

A careful description of the method of conducting the tests should be given. The same person gave all the tests and made the directions uniform in all the rooms. After stating to the young people that a reading exercise in the nature of a test was to be given to their room for the purpose of comparison with the other rooms, the papers were distributed face down upon each desk. Then the directions were given that on a signal all were to read silently, beginning with the first column on p. 3 , for a period of five minutes, after which they would be examined upon what they had read. A signal to stop would be given, after which each one was to mark the place where he or she finished reading. They were cautioned not to try to memorize figures or reread any of the difficult parts, and were ordered to proceed as they would do in reading any newspaper article in which they might be interested. When all were at attention the signal was given to begin, and for five minutes there was no interruption of any kind while all were reading.

When the signal to stop was given each pupil checked the last word read and wrote his or her name on the paper. Then these were collected. The children were next supplied with paper and were asked to write a complete account of what they had just read. In future references this exercise will be called the word test. They were allowed all the time desired, except in a very few cases where individuals wrote an unusual amount. After these papers were collected a set of ten questions, covering the subject-matter just read, was placed upon the blackboard and the children were asked to answer them briefly. These papers will be referred to as the 
percentage test. About two of the columns of the reading were covered by the questions, which might consequently extend over more ground than some had read. If so, each one was directed to answer only as far as he or she had gone in the reading. For instance, if a child read 506 words he would answer or attempt to answer only seven questions. These last papers were graded upon a percentage basis, like regular test work in school. If a pupil read only far enough to answer five questions, each answer counted 20 per cent; while if he read as much or more than was covered by the questions, he could answer all ten questions, each answer being valued at ro per cent.

The attempts to reproduce an account of what was read, or the word tests, were recorded by counting the total number of words written. So there were two tests of reproduction, one for words reproduced in a narrative form and one graded by percentage on the answers to questions. Thus it will be seen that an attempt was made to measure both the quantity and the quality of the reproduction or comprehension. The percentage basis of judging comprehension was somewhat more satisfactory, in that it is a more common form of rating. In many cases the record of the number of words reproduced means practically nothing regarding the ability of the child in comprehension, for some wrote many meaningless phrases and jumbles of words. Often the phrases written related to other subjects called to mind in some way by the reading material. Others wrote briefly, telling excellently in a few words what was read. In general, however, the number of words reproduced is a fair test of the ability in comprehension. Yet most of the comparison is made on the basis of percentage method of judging the comprehension of the subject-matter read.

The same plan of procedure was used in all the grades except that the third and fourth grades had different material and read in the first test a story of Daniel Boone in Eggleston's Stories of Great Americans for Little Americans (American Book Company, I895), beginning with p. 76 .

Late in March, after nearly six months of school work, the second set of tests was given in the same manner. The material was taken from a different page of the same periodical; the matter 
was, therefore, different from that used in the fall. The four upper grades read p. I instead of p. 3 in the same issue of Current Events; while the third and fourth grades read the story of Audubon, beginning with p. II I, instead of the one about Boone. So in all cases the subject-matter was new to all concerned and of about the same relative difficulty. The greater part of the fall test in Current Events was an account of some special elections for Congress, while in the spring it consisted chiefly of an article upon the tariff.

Check tests were given to prevent any errors, to show the relative character of the subject-matter, and to enable the experimenter to secure previous experience in their conduction. The check tests were given in a third- and fourth-grade room in the same school system, which room was not included in the later tests, and in the first-year English class in the high school. The same reading material given to the four upper grades in the fall and spring tests was given to this high-school class on consecutive days; and the lower-grade reading based upon the stories of Boone and Audubon were given but a day apart in the third- and fourth-grade room. These tests show the material for the lower grades to be relatively equal in difficulty for reading and comprehending; and the same fact to be true for the upper-grade tests.

TABLE I

Showing Comparison of the Two Check Tests: Percentage of Gain or Loss

\begin{tabular}{|c|c|c|c|}
\hline & Change in Rate & $\begin{array}{c}\text { Change in } \\
\text { Reproduction }\end{array}$ & $\begin{array}{l}\text { Change in Percentage } \\
\text { of Correct Answers } \\
\text { to Questions }\end{array}$ \\
\hline $\begin{array}{l}\text { Freshmen } . \ldots \ldots \ldots \ldots \\
\text { Fourth grade. } \ldots \ldots \ldots \ldots \\
\text { Third grade..... }\end{array}$ & $\begin{array}{l}+3.6 \\
+3 \\
-2.4\end{array}$ & $\begin{array}{l}+\quad 3.8 \\
+\quad 0.7 \\
+186\end{array}$ & $\begin{array}{l} \pm 42 \\
\pm \quad 4 \cdot 4 \\
-\quad 6\end{array}$ \\
\hline
\end{tabular}

Table I shows the percentage of gain or loss as found in the two check tests given on consecutive days. The small percentage of difference in most cases shows the material to have been fairly well selected. As an example, the Freshmen read 3.6 per cent lower, wrote 3.8 per cent more words, and averaged 42 per cent better in the percentage grades on the second test than in the first.

Over half of the children in the third grade made no attempt at reproduction in the first test, which explains the gain there in 
word reproduction. This result may have been due to the fact that the children had never been requested to attempt such a thing; for they told the teacher afterward that they did not understand what was wanted.

There was a large increase in the first-year high-school percentage grades in the check test. In this class were ten tuition pupils who said afterward that they were not used to having anyone other than their regular teacher give tests and were consequently confused on the first occasion but "knew better what to do" in the next one. This may account in part for the big gain which the second test shows over the first one. These two records practically are the only places where the check test did not show results which were nearly the same. Better directions and a somewhat different method of approach were gained by the experimenter from this experience with the check tests.

The words each child read were counted and tabulated, together with the number of words reproduced and the percentage grade upon the questions answered. In addition to making the averages for each room and each grade, the mean variation was figured for each child and the records include also the variation from the average, as suggested by Thorndike in his Manual of Mental and Social Measurements under the head of "Reliability of Measures." That is, the average mean variation is divided by the square root of the number of cases involved. The medians for each room are also included; and then to make the figures for the reading rate correspond with other experimenters, the result has been expressed in the number of words read per minute.

In order to get a single unit of measurement for comparison of all the grades, the percentage grade was multiplied by the number of words read per minute; for the reading ability depends both upon the rate of reading and the ability to comprehend. The one who can read rapidly and comprehend equally well certainly is a better reader than one whose comprehension is the same, but who reads more slowly.

Table II gives an illustration of the results from the pupils of one teacher, and Table III gives a summary of the results from all the grades which were tested. 


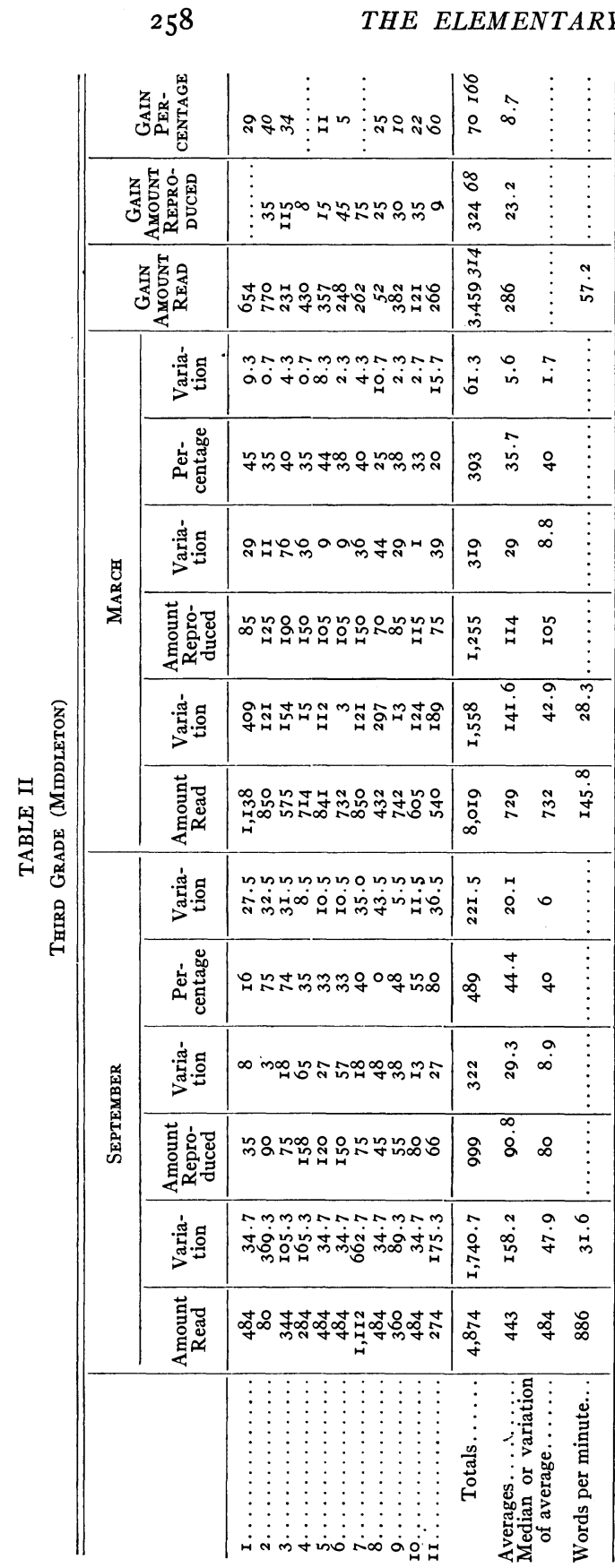

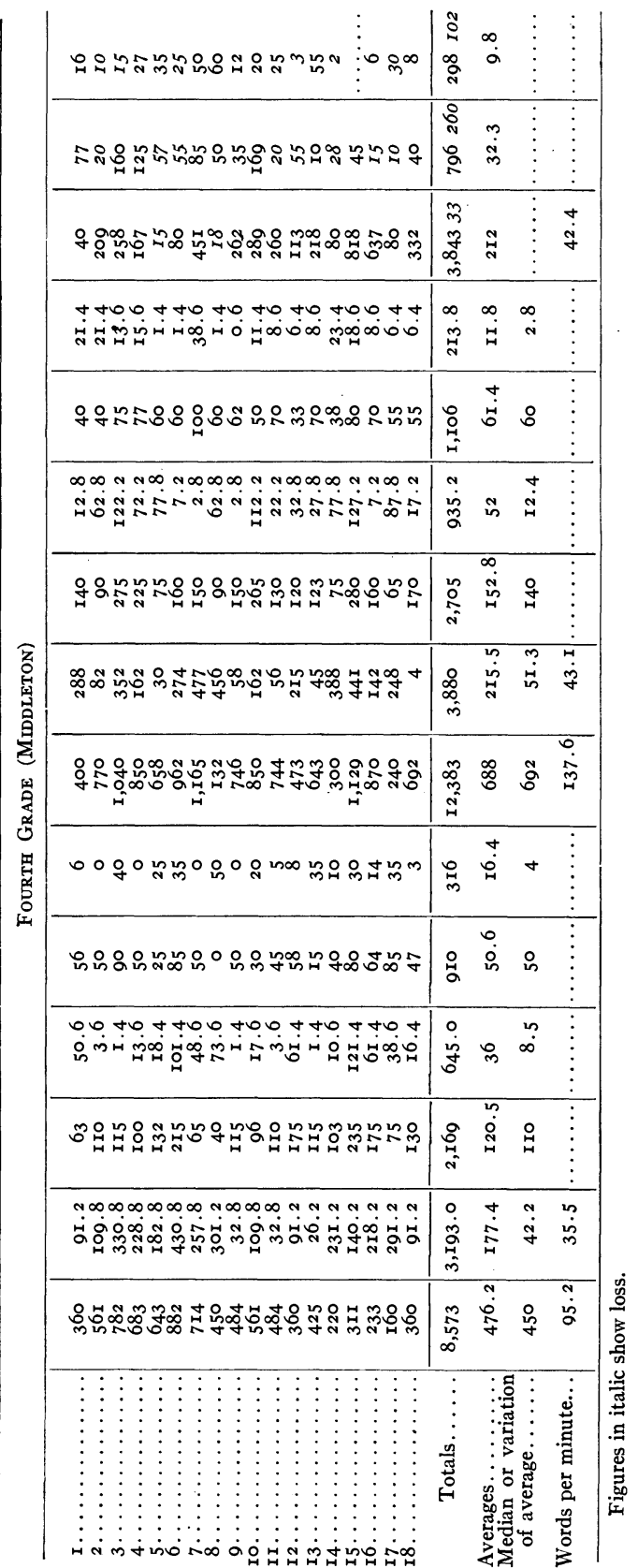




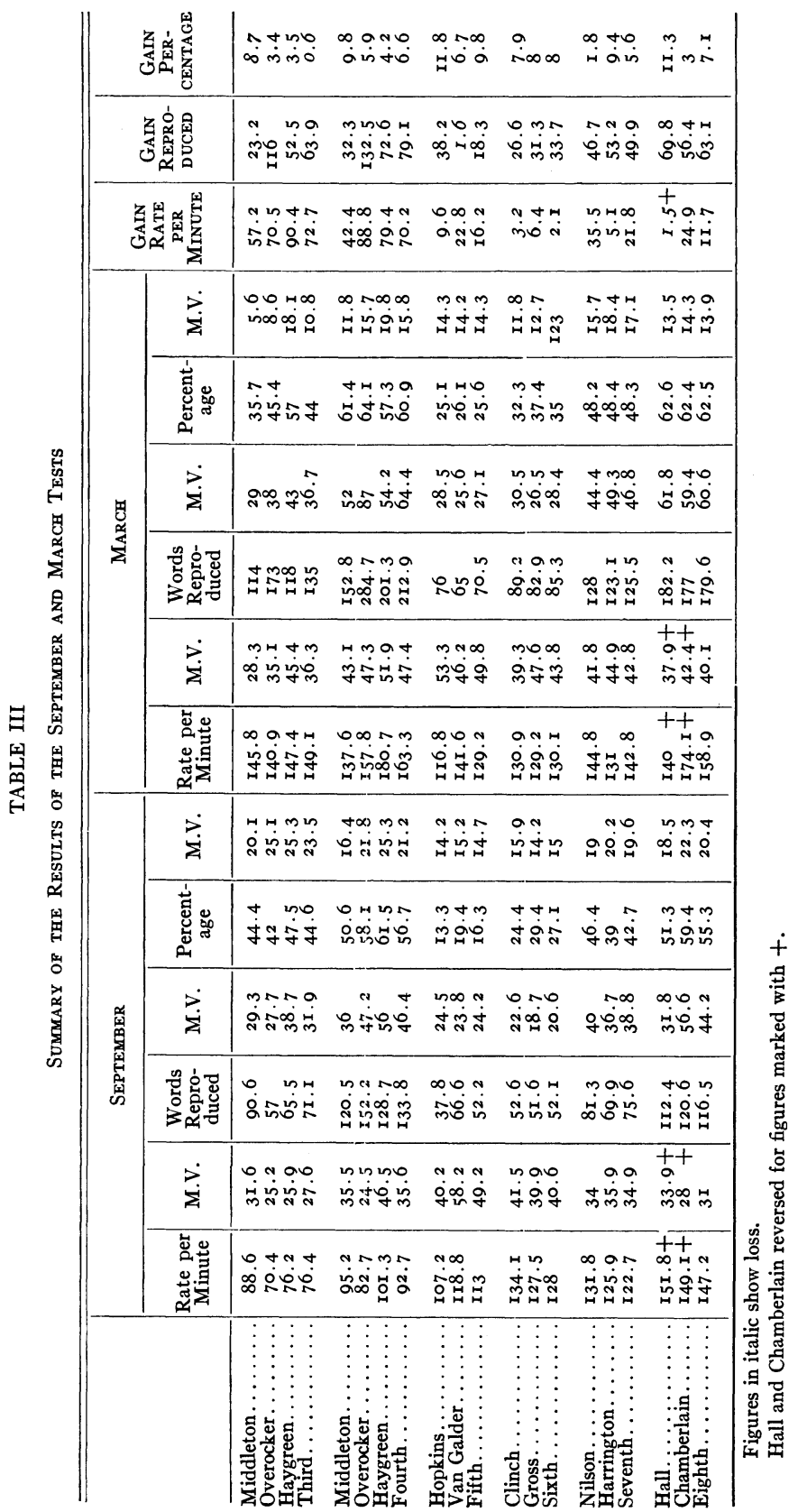

This content downloaded from 193.051.085.197 on April 27, 2018 13:06:40 PM All use subject to University of Chicago Press Terms and Conditions (http://www.journals.uchicago.edu/t-and-c 


\section{DESCRIPTION OF RESULTS}

Variations in same grade.-One of the most noticeable results is the wide variation within single grades, both in rate of reading and in reproduction. Courtis found this in his test as far as he had gone, but these variations are even greater than those found by him. Table IV, taken from the spring test (Freshmen were excepted, although the work was the same as was taken in the fall), shows this remarkable variation without further comment.

TABLE IV

VARIations Within Same Grades

\begin{tabular}{|c|c|c|c|c|c|c|}
\hline \multirow{2}{*}{ Grades } & \multicolumn{2}{|c|}{ RATE OF READING } & \multicolumn{2}{|c|}{ WORDS REPRODUCED } & \multicolumn{2}{|c|}{ Percentage Grades } \\
\hline & High & Low & High & Low & High & Low \\
\hline Freshmen. & $\mathrm{I}, \mathrm{or} 4$ & 399 & 260 & 85 & 100 & 27 \\
\hline Eighth grade. & $\mathrm{r}, 720^{\circ}$ & 233 & 425 & 60 & 98 & 29 \\
\hline Seventh grade. & $r, 365$ & 233 & 275 & I7 & roo & 0 \\
\hline Sixth grade.... & $\mathrm{I}, \mathrm{IO5}$ & 185 & 180 & 35 & 90 & 0 \\
\hline Fifth grade. & $\mathrm{I}, 545$ & 233 & r6o & 0 & 68 & $\circ$ \\
\hline Fourth grade. & $r, 736$ & Iro & $45^{\circ}$ & 65 & 100 & 30 \\
\hline Third grade. . & $r, 183$ & $35^{6}$ & 280 & 70 & 85 & Io \\
\hline
\end{tabular}

TABLE V

Variations in Different Grades

Percentage of Children in Lower Grades Doing Better Work than Those in Upper Grades

\begin{tabular}{|c|c|c|c|c|c|c|c|c|c|}
\hline & \multicolumn{9}{|c|}{ THIRD Grade ExCEeding Fourth } \\
\hline & \multicolumn{3}{|c|}{ Rate } & \multicolumn{3}{|c|}{ Words Reproduced } & \multicolumn{3}{|c|}{ Percentage } \\
\hline & \multicolumn{3}{|c|}{$35 \cdot \mathrm{x}$} & \multicolumn{3}{|c|}{10.8} & \multicolumn{3}{|c|}{13.5} \\
\hline & \multicolumn{9}{|c|}{ UPPER GRADES } \\
\hline & \multicolumn{3}{|c|}{ Rate } & \multicolumn{3}{|c|}{ Words Reproduced } & \multicolumn{3}{|c|}{ Percentage } \\
\hline & 6 & 7 & 8 & 6 & 7 & 8 & 6 & 7 & 8 \\
\hline $\begin{array}{l}\text { Fifth grade...... } \\
\text { Sixth grade...... } \\
\text { Seventh grade.... }\end{array}$ & $\begin{array}{l}42.6 \\
\cdots \cdots \\
\cdots \cdots\end{array}$ & $\begin{array}{l}36.1 \\
35 \cdot 5 \\
\ldots \ldots\end{array}$ & $\begin{array}{l}29 \cdot 5 \\
29 \cdot 4 \\
27 \cdot 7\end{array}$ & $\begin{array}{l}24 \cdot 6 \\
\cdots \cdots \\
\cdots \cdots\end{array}$ & $\begin{array}{r}8.2 \\
\mathrm{I} 5.7\end{array}$ & $\begin{array}{l}\circ \\
2 \\
14.8\end{array}$ & $\begin{array}{r}26.2 \\
\ldots \ldots\end{array}$ & $\begin{array}{l}\mathrm{I} 3 \cdot \mathrm{I} \\
\mathrm{I} 5 \cdot 7 \\
\cdots \cdots\end{array}$ & $\begin{array}{c}\circ \\
4 \\
24 \cdot I\end{array}$ \\
\hline
\end{tabular}

Table V, taken from the pupils' spring test, shows another phase of the variation, namely, that of individuals in different 
grades. It will be seen from this table that many children in lower grades excel their schoolmates in higher grades. Thus 29.5 per cent of the fifth-graders excel the average rate in reading of the eighth grade; 36 . I per cent of them excel the seventh-grade average, and 42.6 per cent excel the average for the sixth grade.

In reproduction there are smaller numbers of children who are superior to those of higher grades; but sixteen children, or 26.2 per cent, excel the average of the sixth grade; and but eight, or I5.7 per cent, exceed the seventh-grade average, and none are superior to the eighth. Other interesting comparisons may be found by a study of the table.

Need for standardized material.-This test clearly shows one fact: that it is not possible, in a test of this kind, where two different passages are used, to compare all grades with each other; for with two different kinds of reading material it is impossible to get a relative comparison for the grades which read different matter. Comparisons can be made, therefore, in this case only within the two groups. This is shown by the table giving the summary for all grades (Table III), where it will be seen that the fourth grades exceeded the fifth, sixth, and seventh grades, not only in the rate of reading, but in the number of words reproduced and in the percentage grades for comprehension. Of course, this is caused by the difference in reading material.

Improvement from lower to upper grades.-One would expect to find an increase both in speed and reproduction from the lower grades to the higher. This increase is not shown fully in this test because of the difference in the material, as has already been pointed out. However, increase of ability in general is shown in most cases, though there are a few exceptions. The rate of speed, ability in reproduction as measured by words, and the comprehension measured by percentage marks, for both the fall and spring tests, are easily deducible from the tables. One notices the regularity of the improvement from grade to grade in quality of comprehension. It is very striking, on the other hand, that in the reading rate there is little increase after the fifth grade. Courtis found the same fact for careful reading in the one school which he has reported in the April, I9I4, number of the Elementary School Teacher. 
These figures show that the lower grades are very important in the development of reading, for there were made the greatest gains in the mechanics of reading. The third and fourth grades nearly doubled their reading rates from September to March. In ability to write the story about what was read the third grade nearly doubled in efficiency, while the fourth grade increased about $5^{\circ}$ per cent. The tables show a great increase in composition and comprehension everywhere except in one fifth-grade room, where there was a slight loss.

\section{TABLE VI}

Showing Percentage Increase of the Spring Test in the Reading Rate

\begin{tabular}{|c|c|c|c|}
\hline Grade & Fall Rate & Spring Rate & $\begin{array}{l}\text { Percentage of } \\
\text { Increase }\end{array}$ \\
\hline $3 \ldots \ldots \ldots$ & 76.4 & I $49 . \mathrm{I}$ & 95.2 \\
\hline $4 \ldots$ & $9^{2} .7$ & I63.3 & 76.1 \\
\hline $5 \ldots$ & Ir3 & I 29.2 & $\mathrm{I} 4 \cdot 3$ \\
\hline $6 \ldots$ & I 28 & I3O.I & $\mathrm{I} .2$ \\
\hline $7 \ldots$ & I22.7 & 142.8 & I6. 4 \\
\hline $8 \ldots$ & $\mathrm{I} 47.2$ & I 58.9 & 8 \\
\hline
\end{tabular}

As shown in Table III, the third grades declined in the percentage grades in the second test, owing to a heavy loss in one room, which was not overcome by the slight improvement made in the other two rooms. The loss, however, was but six-tenths of I per cent. This was the only grade in which the average efficiency in comprehension decreased between the fall and spring tests. One fourth-grade room had a poorer average, but it was offset by the other two fourths, which showed marked improvement. One sixth grade and one of the eighth grades read in the spring at a slower rate than they did in the fall, showing an average loss of 3.2 words per minute and I.5 words per minute, respectively. These were the only rooms in which there was any loss in rate or comprehension.

Table VII, based upon the product of the rate of reading in words per minute times the percentage grade, shows this great improvement clearly. All the grades increased materially. One room, an eighth, showed a lower efficiency in the spring than in the fall, but the other eighth increased more than enough to make the average, for the whole grade showed an increase. 
Comparison of the different systems of teaching reading.-All the children below the sixth grade started with the Ward system of reading, except about one-half of Miss Middleton's third-grade room, which had the Howe system. One reason for putting the

\section{TABLE VII}

Showing Reading Ability Based upon a Single Index, the Product of the Rate Times the Percentage Grade

\begin{tabular}{|c|c|c|c|}
\hline & Fall & Spring & Gain \\
\hline 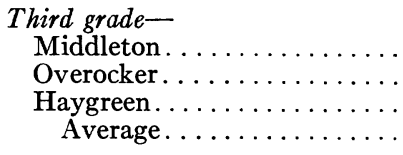 & $\begin{array}{l}39.4 \\
29.6 \\
36.2 \\
34.1\end{array}$ & $\begin{array}{l}52 \cdot I \\
64 \\
75 \cdot 2 \\
65.6\end{array}$ & $\begin{array}{l}\mathrm{I} 2 \cdot 7 \\
34.4 \\
39 \\
28.5\end{array}$ \\
\hline 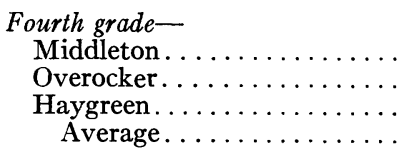 & $\begin{array}{l}48.2 \\
48.1 \\
76 \\
54.6\end{array}$ & $\begin{array}{r}84 \cdot 5 \\
\text { IOI.2 } \\
\text { IO3.5 } \\
99 \cdot 5\end{array}$ & $\begin{array}{l}36.3 \\
53.2 \\
27.6 \\
44.9\end{array}$ \\
\hline $\begin{array}{l}\text { Fifth grade- } \\
\quad \text { Hopkins } \ldots \ldots \ldots \ldots \ldots \ldots \ldots \\
\quad \text { Van Galder } \ldots \ldots \ldots \ldots \ldots \ldots \\
\quad \text { Average } \ldots \ldots \ldots \ldots \ldots\end{array}$ & $\begin{array}{l}\mathrm{I} 4 \cdot 3 \\
23 \\
\mathrm{I} 8.4\end{array}$ & $\begin{array}{l}29 \cdot 3 \\
37 \\
33 \cdot \mathbf{I}\end{array}$ & $\begin{array}{l}\text { I5. I } \\
\text { I3.9 } \\
\text { I4. }\end{array}$ \\
\hline 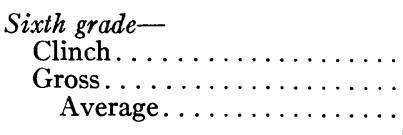 & $\begin{array}{l}32.7 \\
37.2 \\
34.7\end{array}$ & $\begin{array}{l}42 \cdot 3 \\
48 \cdot 3 \\
45 \cdot 5\end{array}$ & $\begin{array}{r}9.6 \\
\text { II. I } \\
\text { I0.8 }\end{array}$ \\
\hline $\begin{array}{l}\text { Seventh grade- } \\
\quad \text { Nilson. } \ldots \ldots \ldots \ldots \ldots \ldots \ldots \\
\text { Harrington } \ldots \ldots \ldots \ldots \ldots \ldots \\
\quad \text { Average } \ldots \ldots \ldots \ldots \ldots\end{array}$ & $\begin{array}{l}50.6 \\
49.1 \\
52.4\end{array}$ & $\begin{array}{l}69.8 \\
63 \cdot 4 \\
68.9\end{array}$ & $\begin{array}{l}19.2 \\
14.3 \\
16.5\end{array}$ \\
\hline $\begin{array}{l}\text { Eighth grade- } \\
\quad \text { Hall. } \ldots \ldots \ldots \ldots \ldots \ldots \\
\text { Chamberlain } \ldots \ldots \ldots \ldots \ldots \ldots \\
\quad \text { Average } \ldots \ldots \ldots \ldots \ldots \ldots\end{array}$ & $\begin{array}{l}76.5 \\
90.2 \\
81.4\end{array}$ & $\begin{array}{l}\text { III } \\
87.4 \\
99.3\end{array}$ & $\begin{array}{r}34.5 \\
2.8 \\
17.9\end{array}$ \\
\hline
\end{tabular}

Figures in italic show loss.

rather difficult reading material offered in the Current Events down so low in the grades was for the purpose of comparing the fifth and sixth grades upon the same reading material; the former learned to read by a severe phonic system (the Ward), while the latter was taught to read by whatever plan the teacher chose to develop. The figures for these two grades show a relation quite similar to the relations of the other similar grades; so that it is impossible to 
draw any conclusion regarding the relative merits of the two different plans for starting the reading work. In other words, there seems to be no more difference between a fifth grade which has had the Ward method and a sixth that has not than there is between the sixth grade and the seventh, neither of which has had the phonic system.

It will be seen that the third-grade children who learned to read by the Howe method did the best reading work in the fall test, 39.338 being its single-index measurement, compared with 29.40 and 34.07 for the other third-grade rooms; while in the spring test it had lost its leading position, scoring 52.05, which put it into third place, for the other figures totaled 75.174 and 63.969. This cannot be attributed to the Howe method entirely, for the teacher in that third grade, although she tried to work both systems, did not carry on the drills as thoroughly as she might, being more interested in the Ward method. Here was clearly shown the loss occurring in a single system when different plans of work are carried out in the same grade. Miss Middleton, the teacher, explained this weakness of her grade by the fact that she had a fourth grade in the room at the same time which was twice as large as her third and somewhat backward. In trying to bring this fourth grade up to standard, she thinks that she might have neglected the third grade somewhat.

Effect of tests. - The children in the spring about reach the plane of development which the grade above them had at the beginning of school in the fall. There should perhaps be some correspondence between spring tests of the grade below and the fall tests of the grade above. Attention should be drawn to two facts which complicate the comparison: that the spring test was given about three months before the close of school, and that the upper-grade children in the fall test were on an average about six months older. With these facts in mind, one would expect the children of the greater maturity, who had had three months more of school work, to do much better work than their younger rivals. In the fall, however, these older children had just returned from their vacations and doubtless lost somewhat in efficiency from the lack of regular school reading exercises. 
In the majority of cases the lower-grade record exceeds that of the grade above in spite of the lack of maturity. This probably is due to the stimulus caused by the test and bears out Woodworth's conclusion in his report, found in the Proceedings of the Mental Hygiene Conference and Exhibit for I9I2, on p. 217, where he urges the value of such tests to prevent dawdling over the school tasks. The apparent superiority of the fourth over the fifth grade is due to the difference in the character of the subject-matter read and is not real. This superiority of the lower grade does not show in the percentage tables nor in the single-index measurement. The latter, however, is largely determined by the former. In speed and word reproduction there is but one place where the younger children did not do better, and that is in the eighth grades, where, as has been before mentioned, some of the children in the fall had seen the paper in advance.

These results furnish a good argument for the value of regularly conducted tests in reading, although the evidence shows that ability in comprehension is less easily stimulated in this way than is the reading rate. Yet by increasing the reading rate, which can be done without any loss in comprehension, the pupils in general would be much stronger readers.

TABLE VIII

Showing Single-Index Rating

\begin{tabular}{|c|c|c|c|c|}
\hline $\begin{array}{l}\text { Gain by Grades for } \\
\text { September and March }\end{array}$ & $\begin{array}{c}\text { Words Read per } \\
\text { Minute }\end{array}$ & $\begin{array}{c}\text { Words } \\
\text { Reproduced }\end{array}$ & $\begin{array}{l}\text { Percentage } \\
\text { Reproduced }\end{array}$ & $\begin{array}{l}\text { Single-Index } \\
\text { Rating }\end{array}$ \\
\hline $\begin{array}{l}\text { Third, spring test. . } \ldots \ldots \ldots \\
\text { Fourth, fall test. . . }\end{array}$ & $\begin{array}{r}\mathrm{I} 49 . \mathrm{I} \\
92.7\end{array}$ & $\begin{array}{l}\text { I35 } \\
\text { I33.8 }\end{array}$ & $\begin{array}{l}44 \\
56.7\end{array}$ & $\begin{array}{l}65.6 \\
54.6\end{array}$ \\
\hline $\begin{array}{l}\text { Fourth, spring test } \ldots \ldots \ldots \\
\text { Fifth, fall test } \ldots \ldots \ldots \ldots\end{array}$ & $\begin{array}{l}\text { I63.3 } \\
\text { II3 }\end{array}$ & $\begin{array}{r}212.9 \\
52.2\end{array}$ & $\begin{array}{l}60.9 \\
16.3\end{array}$ & $\begin{array}{l}99.5 \\
\mathrm{I} 8.4\end{array}$ \\
\hline $\begin{array}{l}\text { Fifth, spring test.... } \\
\text { Sixth, fall test. . . . }\end{array}$ & $\begin{array}{l}\mathrm{I} 29 \cdot 2 \\
\mathrm{I} 28\end{array}$ & $\begin{array}{l}70.5 \\
52.1\end{array}$ & $\begin{array}{l}25.6 \\
27.1\end{array}$ & $\begin{array}{l}33 \cdot 1 \\
34 \cdot 7\end{array}$ \\
\hline $\begin{array}{l}\text { Sixth, spring test. } \ldots \ldots \ldots \\
\text { Seventh, fall test. . . } \ldots \ldots\end{array}$ & $\begin{array}{l}\text { I30. I } \\
122.7\end{array}$ & $\begin{array}{l}85.3 \\
75.6\end{array}$ & $\begin{array}{l}35 \\
42 \cdot 7\end{array}$ & $\begin{array}{l}45 \cdot 5 \\
52 \cdot 4\end{array}$ \\
\hline $\begin{array}{l}\text { Seventh, spring test... } \\
\text { Eighth, fall test..... }\end{array}$ & $\begin{array}{l}\mathrm{I} 42.8 \\
\mathrm{I} 47.2\end{array}$ & $\begin{array}{l}125.5 \\
116.5\end{array}$ & $\begin{array}{l}48 \cdot 3 \\
55 \cdot 3\end{array}$ & $\begin{array}{l}68.9 \\
8 \mathrm{I} .4\end{array}$ \\
\hline
\end{tabular}

Table VIII and Chart I present a summary of the gains in efficiency from the fall to the spring testṣ for each grade taken as a whole. 
The conclusion to be drawn from Table VIII is that speed and ability to reproduce words are more easily stimulated by tests than the real mental development, if such be measured by the percentage marks. However, it seems to the writer to be a good argument for holding such tests, for it gives a goal toward which to work, for

CHART I

Graphic Representation of the Facts Presented in Table VIII

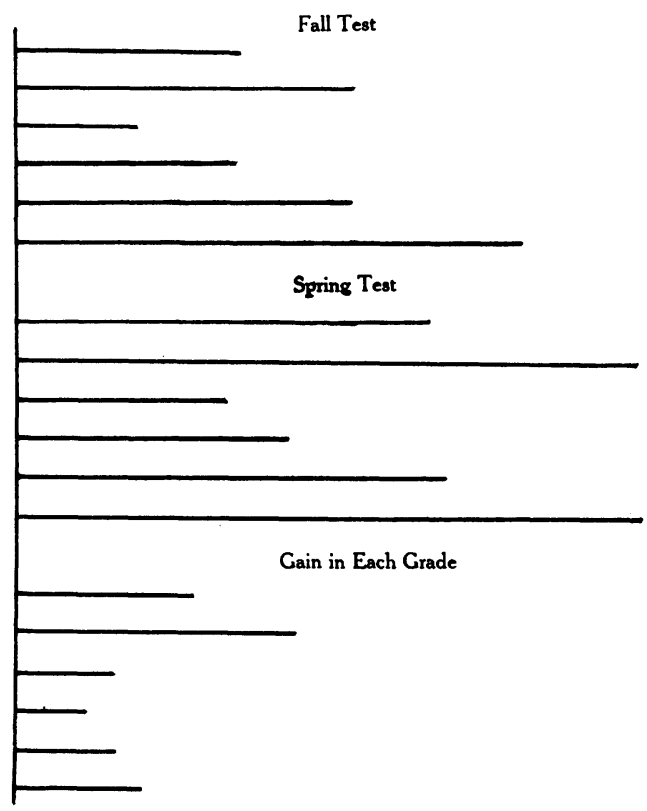

both the children and teachers, and tends to do away with the dawdling over the reading tasks. Altogether it is a safe conclusion from all these statistics to state that the real comprehension depends more largely upon regular mental development and is less easily stimulated than the rate.

Relation of speed to comprehension.-The work previously quoted of Quantz, Abell, and others interested the writer in an attempt to find the correlation between the reading rate and the comprehension. No definite result can be stated, but it would seem that the rapid readers usually are strong in comprehension, 
although there are many exceptions. The high-school Freshmen show the most correlation, but that is far from perfect. Of course it must be borne in mind here, as has been pointed out before, that high speed with an equal percentage of reproduction represents much higher general efficiency than a lower speed with the same reproductive ability. That is, the boy who reads a thousand words in five minutes and reproduces 50 per cent of it has a much higher reading efficiency than the one who reads but five hundred words with the same power of comprehension. So a rapid rate is greatly to be desired, and being more open to stimulus it can be secured by special emphasis, such as tests of this kind.

\section{SUMMARY}

The conclusions drawn from this study are not stated dogmatically and may have to be altered, should further investigation be made. However, the author believes the following conclusions are justified by the evidence developed:

Great variation exists in reading ability between different individuals in the same grade, and many children in lower grades are much better readers than the average of the upper grades.

In developing a standard reading scale to show the relative efficiency of different grades it will be necessary to use the same subject-matter for all grades, or else the materials should be so standardized that their relative difficulty is known and can be used in judging the results, or else there should be some overlapping tests.

In careful reading the rate increases but slowly in school work after the fifth grade. The increase in comprehension, however, increases regularly from the lower to the upper grades.

The third and fourth grades are places with the possibilities for wonderful development, especially in the mechanics of reading. The effects of starting the reading with a phonic system like the Ward are not evident in the reading of the upper grades. Tests tend to stimulate the work in reading, but have more effect upon the reading rate than upon the ability to comprehend what is read.

No definite conclusions were obtained upon the correlation between speed and comprehension; yet it is safe to say that an 
increase in the rate of reading does not decrease ability in comprehension.

\section{BIBLIOGRAPHY}

Abell, Adelaide, "Rapid Reading, Advantages and Methods," Ed. Rev., VIII (I894), 283.

Bowden, Josephine H., Learning to Read. Doctor's Dissertation, University of Chicago, I9Ir.

Brown, H. A., "Measurement of the Efficiency of Instruction in Reading," Elem. Sch. Teacher, XIV (I9I4), 477-90.

Courtis, S. A., "Standard Tests in English," Ibid., 374-92.

Dearborn, W. F., "Psychology of Reading," Columbia Contributions to Philosophy and Psychology, XIV, No. I (I906).

Huey, E. B., Psychology and Pedagogy of Reading. New York, I909.

Judd, Charles H., "Reading Tests," Ibid., 365-73.

Quantz, J. O., "Problems in Psychology of Reading," Psych. Rev. (Mon. Supp.), I897.

Reudiger, "Field of Distinct Vision," Columbia Contributions to Philosophy and Psychology, XVII, No. I (I907). 